\title{
RECAPTCHA ALL OVER AGAIN
}

\section{Are you a robot?}

\section{BY AARON MOSKALIK}

$\mathrm{G}$ eorge swished the coffee across his tongue. Unpalatable, but only a hint of bitterness. "It feels like Tuesday to me." He poured in three creamers and four sweeteners before taking a more robust hit.

"You just said Thursday." Bill had his feet on his desk while bouncing his ball. Desk, wall, hand. Desk, wall, hand. Ba-doom pa. Ba-doom pa.

George ground his teeth against the repetitive sound. "I was wrong or I wouldn't be reliving this.”

"Maybe you're a robot. Everyone knows robots can't read calendars." Bill laughed at his own joke.

George grimaced. He wished it were that easy. The CAPTCHA VR was carefully devoid of any obvious clues. The time on his screen was 9:34, but no date. The calendar app wouldn't open. He'd read his e-mail, even the spam, without finding a single clue. "I need to get this right or I can't sign up for benefits."

"Sucks to be you." Bill started bouncing his ball again. "Robots don't need benefits."

Bill was Bill no matter what day it was. George pushed back from the desk. He needed to stretch his legs.

The corridor to the breakroom was long and straight. Angela was coming the other way, cup of coffee in hand. He lowered his eyes, pretending to be deep in thought, then last second, a nod and a smile. Whew. He got a hint of Angela's perfume. VR was remarkably detailed these days.

Jeanine was standing at the windows. She smiled at him before taking another sip of coffee, then gestured to the street below. "Traffic's heavy today."

Cars zipped through the intersection from all directions without slowing. George cringed but the traffic AI was flawless. There'd been zero collisions since they outlawed human drivers. "I remember they used to have us identify traffic lights to prove we were human. So much easier than today's CAPTCHA tests."

"What's a traffic light?" Jeanine's lips curled to indicate a joke. "Those weren't just CAPTCHA tests. We were training the first self-driving cars. What was the point though? Robots don't need traffic lights."

"I suppose they had to share the road with humans at first, follow our rules." George caught himself. "You're not really Jeanine though, are you? These simulations are scary good."

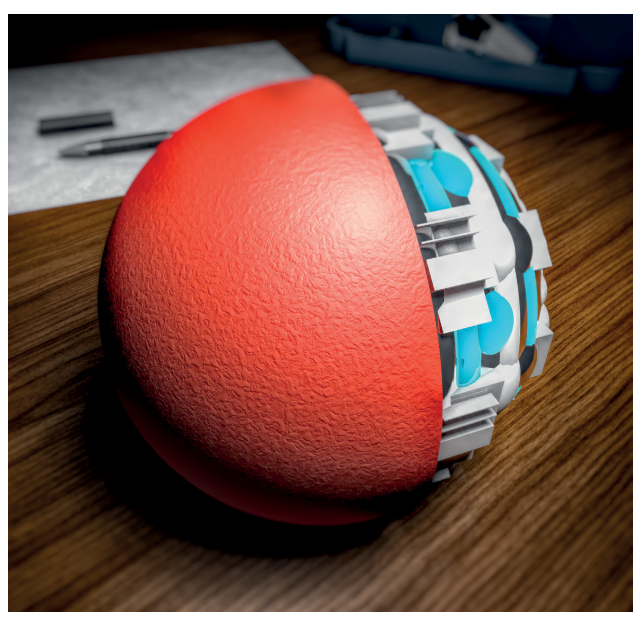

Jeanine laughed. "Not this good, I hope. But I was about to ask you the same thing. Signing up for a benefits account?"

George nodded. "It's my second time through. I guessed Thursday the first time."

"I guessed Wednesday." Jeanine took another sip. "With traffic this heavy, it can't be Monday or Friday. That just leaves Tuesday."

George nodded. "The coffee tastes early week -"

But Jeanine had disappeared as soon as she guessed. She was right too. Had to be. "Tuesday," George repeated.

Back at his desk, in the real world, George tossed the VR headset behind his monitor. "Welcome to Beneflex," his screen read. He was in with only half the morning wasted. Something was off though.

Bill's ball sat in the centre of his desk next to a box. He turned, his face blank, but affected a smile and stuck out his hand. "George, it's been real."

George's handshake was tentative. "What's going on?"

Bill picked up his box. "My services are no longer required. My own fault really. My mind's been elsewhere lately. Oh, here." $\mathrm{He}$ handed George a flyer from a stack in his box. "My band's playing at the Greyhound this weekend."

"Captain Captcha and the Robots. Live for the Weekend tour." George read.

"Yeah, we're throwbacks. Industrial Beatles, if you can imagine that."

George frowned at the flyer. "No, I really can't."
D NATURE.COM Follow Futures:

\section{y @NatureFutures}

$f$ go.nature.com/mtoodm
Bill shot George with a finger gun as he moved towards the door. "Cool, see you there. Hey, Jeanine. Concert this weekend." He handed her a flyer.

"You forgot your - " But Bill was already gone. "Ball," George finished to Jeanine. "That was odd."

Jeanine cast a furtive glance at Bill's retreating back and dropped the flyer on his former desk. "You don't know the half of it. Come with me." She pulled George out the door. A woman was coming the other way down the hall. Jeanine ducked behind George.

Déjà vu tingled down George's spine. "It's just Angela."

"No, it is not," Jeanine said from behind him. "Look closer."

Jeanine was right, this wasn't Angela. Maybe her twin. Her head was tilted down as if studying the cup of coffee in her hand. When they got close, she glanced up. There was something off with her eyes. An emptiness. She smiled. "Hi, I am Angelique."

"Uh, hi." George held out his hand. "I'm George."

Angelique looked at his hand then at the cup in her own. "Would you like my coffee? Robots don't need coffee."

"No - "Jeanine pulled George back the way they came. "Thanks."

Angelique looked puzzled, then walked into Angela and Jeanine's office.

"See what I mean?" Jeanine hissed.

George shook his head. "Where is Angela?"

"She was sacked this morning." Jeanine shuddered. "Minutes later, that thing walked in."

"Bill was let go as well." George chewed his lip. A familiar sound echoed from his office. Ba-doom pa. Ba-doom pa. He gestured for Jeanine to stand back as they approached the door.

Bill was back, feet on his desk, bouncing his ball. Desk, wall, hand. Desk, wall, hand. No wait, uncannily not Bill. But he was reading Bill's flyer. The robot looked up. "Hi, I'm Will. You must be George."

George did his best to smile. He nodded to the flyer. "You planning on going to Bill's concert?"

"Nah." Will handed George the flyer. "Robots don't need weekends." -

Aaron Moskalik starts his day writing speculative fiction in Southfield, Michigan, before dropping his daughter at school and earning a pay cheque as a software architect. To view his published works, visit aaronmoskalik.com. 